\title{
PERBEDAAN PERILAKU MEMBERIKAN TEMPAT DUDUK ANTARA PENUMPANG PEREMPUAN DAN LAKI-LAKI REMAJA AKHIR DI KRL JABODETABEK
}

\author{
Aries Yulianto $\mathbb{( 1 )}^{1)}$ dan Jihan Marwa Salsabil Permana $\bigoplus^{2)}$ \\ ${ }^{1,2}$ Psikologi, Fakultas Humaniora dan Bisnis, Universitas Pembangunan Jaya \\ 1,2 Jl. Cendrawasih Raya Blok B7/P, Sawah Baru, Ciputat, Tangerang Selatan, Banten, 15413 \\ E-mail : aries.yulianto@ upj.ac.id ${ }^{1)}$, jihan.marwasalsabilpermana@student.upj.ac.id ${ }^{2}$
}

\begin{abstract}
ABSTRAK
Kepadatan penumpang KRL Jabodetabek masih terjadi, meskipun dalam kondisi pandemi COVID-19. Dengan adanya kepadatan di KRL, mendapat tempat duduk merupakan suatu keuntungan bagi penumpang. Memberikan tempat duduk bagi penumpang lain merupakan salah satu perilaku menolong karena memberikan keuntungan bagi orang lain. Di sisi lain, remaja akhir diharapkan telah mencapai kematangan moral dan emosi, termasuk perilaku menolong. Studi-studi sebelumnya menunjukkan adanya perbedaan perilaku menolong antara perempuan dan laki-laki berusia remaja akhir, namun belum ada yang meneliti tentang perilaku menolong di KRL. Penelitian ini ingin mengetahui apakah ada perbedaan perilaku menolong memberikan tempat duduk antara perempuan dan laki-laki berusia remaja akhir di KRL rute JakartaBogor. Penelitian dilakukan pada 389 responden (193 perempuan dan 196 laki-laki) berusia 15-20 tahun, minimal 3 kali menggunakan KRL di saat jam kerja, dan minimal pernah satu kali memberikan tempat duduk kepada penumpang lain. Pengukuran perilaku menolong menggunakan Skala Guttman dengan menanyakan mana saja dari 8 jenis penumpang KRL yang pernah diberikan tempat duduk. Hasil analisis data menunjukkan diketahui adanya urutan perilaku memberikan tempat duduk dalam tingkat kebutuhan, namun ada perbedaan antara remaja akhir laki-laki dan perempuan. Hasil uji beda juga menunjukkan perilaku menolong remaja akhir laki-laki lebih tinggi dari perempuan.
\end{abstract}

Kata Kunci: Perilaku Menolong, Memberikan Tempat Duduk, KRL Jabodetabek, Remaja Akhir

\section{PENDAhuluan}

Data Badan Pusat Statistik (sebagaimana dikutip dalam Rahayu, 2019) menunjukkan bahwa terjadi peningkatan kepadatan Kereta Rel Listrik (KRL) Jabodetabek (Jakarta, Bogor, Depok, Tangerang, dan Bekasi) sebesar 0,68\% pada Januari hingga April tahun 2019 dengan penumpang mencapai 138,6 juta orang, mengalami kenaikan dibanding periode yang sama pada tahun 2018. Dikarenakan pandemi, pada awal tahun 2020 jumlah penumpang KRL Jabodetabek hanya sebanyak 122,8 juta orang atau mengalami penurunan $50,46 \%$ dibanding periode yang sama pada tahun lalu. Namun pada Juli 2020, kembali terlihat peningkatan jumlah penumpang KRL Jabodetabek mencapai 400 ribu pengguna per harinya.

Meskipun terjadi penurunan jumlah penumpang, kepadatan penumpang di KRL Jabodetabek tetap terjadi. Artinya, tidak semua penumpang mendapatkan tempat duduk. Apalagi dengan adanya aturan Pembatasan Sosial Berskala Besar (PSBB), dimana ada pengaturan jarak penggunaan tempat duduk di KRL Jabodetabek. Dengan demikian, mendapatkan tempat duduk di KRL Jabodetabek bagi penumpang merupakan suatu keistimewaan.

Sejumlah cerita menunjukkan bahwa remaja yang memberikan tempat duduknya di KRL kepada penumpang lain, seperti pada ibu hamil (Irawan, 2018), namun ada juga remaja yang menunjukkan perilaku berbeda (Aprillia, 2018). Perilaku memberikan tempat duduk di KRL dapat dikatakan merupakan perilaku menolong. Hal ini sesuai dengan pengertian perilaku menolong menurut (Branscombe \& Baron, 2017), yaitu tindakan seseorang yang membantu orang lain, sering kali tanpa ada keuntungan langsung bagi penolong. Memberikan tempat duduk di KRL merupakan salah satu perilaku menolong karena orang yang membantu dapat memberikan keuntungan kepada orang lain, dimana keuntungan yang didapatkan oleh orang yang ditolong berupa kenyamanan dalam KRL dengan mendapatkan tempat duduk, namun penolong tidak mendapatkan keuntungan langsung.

Perilaku menolong di KRL sebenarnya tidak hanya memberikan tempat duduk pada penumpang lain saja, namun memberikan tempat duduk kepada penumpang lain merupakan perilaku menolong sehari-hari di KRL yang paling mudah dan dapat dilakukan oleh hampir semua penumpang KRL. Hal ini sesuai dengan studi pendahuluan yang dilakukan peneliti kepada 15 perempuan dan 15 laki-laki berusia 15-20 tahun, diperoleh hasil bahwa perilaku menolong di KRL yang pernah dilakukan adalah (secara berurutan): memberikan tempat duduk kepada penumpang lain (100\%), meletakkan barang penumpang lain di rak bagasi KRL $(26,7 \%)$, membawakan barang penumpang lain (20\%), 
menolong penumpang lain yang pingsan (13,3\%), membantu mencarikan tempat duduk lansia dan disabilitas $(13,3 \%)$, dan membantu korban pencopetan $(3,3 \%)$. Dengan demikian, dapat dikatakan bahwa perilaku memberikan tempat duduk merupakan perilaku menolong yang paling banyak dilakukan.

Lebih lanjut hasil pada studi pendahuluan ini ditemukan ada perbedaan dalam siapa yang akan diberikan tempat duduk antara remaja perempuan dan laki-laki. Pada responden perempuan, mereka akan memberikan tempat duduk kepada (secara berurutan): perempuan lansia (93\%), ibu hamil (80\%), laki-laki lansia $(60 \%)$, ibu membawa anak $(53 \%)$, perempuan disabilitas (26\%), laki-laki disabilitas (20\%), perempuan dewasa (20\%), laki-laki dewasa (6\%) dan laki-laki dewasa yang sedang sakit $(6 \%)$. Sedangkan pada responden laki-laki, mereka akan memberikan tempat duduk kepada: ibu hamil (86\%), perempuan lansia (86\%), laki-laki lansia (80\%), laki-laki disabilitas (66\%), perempuan disabilitas $(60 \%)$, ibu membawa anak $(60 \%)$, perempuan dewasa (33\%), laki-laki dewasa (6\%) dan anak kecil (6\%). Dari hasil ini dapat dikatakan bahwa ada perbedaan pada remaja perempuan dan laki-laki dalam pemberian tempat duduk, dimana perempuan ternyata lebih menolong ke perempuan lansia dan lakilaki lebih menolong kepada ibu hamil. Walaupun ternyata perempuan dan laki-laki usia remaja akhir memiliki kesamaan dalam memberikan tempat duduk di KRL, dimana keduanya tidak memberikan tempat duduk kepada laki-laki dewasa.

Masuknya usia remaja akhir pada diri seseorang setidaknya sudah dapat mengerti norma-norma yang ada pada masyarakat dan sudah berfikir secara cermat. Arwanti (sebagaimana dikutip dalam Septianingsih, 2017) menyatakan bahwa ketika seseorang beranjak pada masa remaja akhir diharapkan telah mencapai kematangan moral dan emosi. Individu yang sudah mencapai kematangan moral dan emosi, mereka tidak hanya menghindari berbagai perilaku negatif, tetapi juga dapat memotivasi untuk berperilaku positif seperti hal nya bekerja sama, empati, toleransi dan peduli. Terdapat perbedaan karakteristik antara remaja perempuan dan remaja laki-laki dimana (Sunarti dkk, 2018) menyatakan bahwa remaja laki-laki memiliki kemampuan kerja sama dan komunikasi $(75,83 \%)$ lebih baik daripada remaja perempuan $(71,25 \%)$, sedangkan remaja perempuan lebih memiliki kemampuan berempati $(79,99 \%)$ dan pemecahan masalah $(75,97 \%)$ lebih tinggi dibandingkan remaja laki-laki memiliki kemampuan berempati $(66,81 \%)$ dan pemecahan masalah $(69,17 \%)$ yang lebih rendah. Regulasi diri dan strategi resilience pada remaja akhir meningkatkan perilaku menolong di Italia (Alessandri dkk, 2014).

Terkait dengan karakteristik remaja akhir yang seharusnya sudah dapat mengerti norma-norma pada masyarakat, sudah mencapai kematangan moral dan emosi maka diharapkan remaja akhir lebih bisa memberikan pertolongan kepada orang lain dibandingkan dengan kelompok usia yang lain. Remaja akhir yang sudah memenuhi karakteristik perkembangan moral dengan memberikan pertolongan kepada orang lain di KRL dengan memberikan tempat duduk. Hal ini dikarenakan bahwa memberikan tempat duduk di KRL adalah salah satu perilaku menolong karena orang yang membantu dapat memberikan keuntungan terhadap orang lain.

Peranan jenis kelamin terhadap kecenderungan seseorang untuk menolong sangat bergantung pada situasi dan bentuk pertolongan yang dibutuhkan. Mahasiswa STIKes ICME Jombang, laki-laki cenderung lebih memberikan bantuan dibandingkan dengan perempuan (Rosyadi dkk. 2018). Di London, Inggris menemukan terdapat perbedaan perilaku menolong antara remaja laki-laki dan remaja perempuan, dimana remaja laki-laki tingkat perilaku menolongnya stabil hingga usia 14 tahun dan sedikit menurun setelah melewati usia 17 tahun. Sedangkan perilaku menolong pada remaja perempuan meningkat hingga usia 16 tahun namun setelah melewati usia tersebut perilaku pro sosial sedikit menurun. Ada perbedaan dalam perilaku menolong berkisar untuk remaja laki-laki antara 8,9$27,9 \%$, dan untuk remaja perempuan antara $12,0-27,5 \%$ Penelitian (Graff, dkk, 2018).

Kembali ke hasil studi pendahuluan yang dilakukan oleh peneliti kepada 30 penumpang KRL remaja, dapat dikatakan adanya urutan dalam perilaku menolong memberikan tempat duduk di KRL yang terlihat dari perbedaan persentase mengenai orang yang akan dibantu. Persentase laki-laki dewasa akan diberikan tempat duduk oleh remaja laki-laki (6\%) dan oleh remaja perempuan (6\%) lebih kecil dibandingkan ibu hamil (80\% pada remaja perempuan dan $86 \%$ pada remaja laki-laki). Begitu pula bila dibandingkan dengan memberikan tempat duduk kepada lansia (93\% pada remaja perempuan dan $86 \%$ pada remaja laki-laki). Bila melihat tingkat kebutuhan akan tempat duduk terkait dengan kondisi fisiknya, lansia dan ibu hamil lebih membutuhkan dibandingkan laki-laki dewasa. Oleh karena itu, peneliti menduga bahwa bila remaja ingin memberikan tempat duduk kepada laki-laki dewasa dan perempuan dewasa yang sebenarnya tidak terlalu membutuhkan, mereka juga akan memberikan tempat duduknya kepada penumpang lain yang lebih membutuhkan, seperti laki-laki lansia, perempuan lansia, hingga ibu hamil. Dengan kata lain, peneliti menduga adanya urutan siapa yang akan diberikan tempat duduk di KRL oleh remaja akhir tergantung dari tingkat kebutuhannya.

Dugaan terhadap urutan di atas dapat diketahui dengan menggunakan skala Guttman. (Yulianto, 2020) menemukan adanya urutan perilaku seksual pra nikah pada remaja berdasarkan tingkat keintiman nya, mulai dari berpegangan tangan (keintiman paling rendah), berciuman, petting, hingga berhubungan seksual (keintiman paling tinggi). Oleh karena itu, menurut peneliti dengan konsep yang sama perilaku menolong 
memberikan tempat duduk di KRL oleh remaja akhir dapat diketahui urutannya. Dengan menggunakan skala Guttman, diharapkan perilaku memberikan tempat duduk di KRL dapat diketahui urutannya seperti dugaan peneliti, yaitu didasari sifat kebutuhan korban. Semakin korban dianggap membutuhkan, semakin besar kemungkinan remaja akhir melakukan perilaku menolong memberikan tempat duduk kepada penumpang tersebut. Urutan yang diduga peneliti yaitu apabila penumpang ingin memberikan tempat duduk kepada penumpang lain yang tidak terlalu membutuhkan (misalnya, laki-laki dewasa ataupun perempuan dewasa) kemungkinan besar juga akan memberikan tempat duduk kepada penumpang yang lebih membutuhkan (misalnya, ibu hamil atau lansia). Tetapi, penumpang yang hanya memberikan tempat duduk kepada orang yang sangat membutuhkan (misalnya, ibu hamil), maka tidak akan memberikan tempat duduk kepada penumpang yang kurang membutuhkan (misal, laki-laki dewasa atau perempuan dewasa).

Berdasarkan pemaparan di atas, peneliti menduga ada perbedaan perilaku memberikan tempat duduk antara penumpang perempuan dan laki-laki berusia remaja akhir di KRL. Perbedaan perilaku tersebut terkait dengan urutan siapa yang akan diberikan tempat duduk berdasarkan tingkat kebutuhannya. Hal-hal inilah yang mendasari penelitian yang akan dilakukan oleh peneliti.

\section{RUANG LINGKUP}

Ruang lingkup dari penelitian ini mencakup:

1. Cakupan permasalahan penelitian ini adalah "apakah ada perbedaan perilaku menolong memberikan tempat duduk antara penumpang perempuan dan lakilaki usia remaja akhir di KRL rute Jakarta-Bogor?"

2. Peneliti menetapkan batasan-batasan dalam penelitian ini sebagai berikut:

Perilaku menolong yang dimaksudkan dalam penelitian ini adalah perilaku memberikan tempat duduk kepada penumpang KRL lainnya. Sedangkan batasan untuk partisipan adalah laki-laki maupun perempuan berusia 15-20 tahun, pengguna KRL rute Jakarta-Bogor minimal sebanyak 3 kali di saat jam kerja, dan minimal pernah satu kali memberikan tempat duduk kepada penumpang lain.

3. Hasil yang diharapkan dalam penelitian ini adalah adanya perbedaan perilaku menolong memberikan tempat duduk antara penumpang perempuan usia remaja akhir dan laki-laki usia remaja akhir di KRL rute Jakarta-Bogor.

\section{BAHAN DAN METODE}

Berikut adalah bahan dan metode pada penelitian ini:

\subsection{Perilaku Menolong}

Membantu orang lain merupakan bagian penting dari masyarakat yang sehat, yang berkontribusi terhadap hasil individu, organisasi, serta masyarakat yang positif (Randall dkk, 2018). Perilaku menolong adalah tindakan seseorang yang membantu orang lain, sering kali tanpa ada keuntungan langsung bagi penolong (Branscombe dan Baron, 2017). Pengertian serupa disampaikan oleh Sparrowe, Soetjipto, dan Kraime (sebagaimana dikutip dalam Jang dkk., 2020), yang mengatakan bahwa perilaku menolong merupakan perilaku yang dimaksudkan untuk memberikan keuntungan kepada anggota kelompok lain atau kelompok secara keseluruhan. Perilaku menolong merupakan tindakan yang bertujuan memberikan kentungan bagi orang lain. Eagly (sebagaimana dikutip dalam Kennedy, 2013) menambahkan perilaku menolong juga termasuk berbagi, menenangkan, memandu, menyelamatkan, serta membela (Hogg dan Vaughan, 2018).

\subsection{Perbedaan Jenis Kelamin dalam Perilaku Menolong}

Perempuan dan laki-laki memiliki perbedaan dalam melakukan tindakan menolong. Sejumlah penelitian menunjukkan bahwa anak perempuan memiliki penalaran moral dan empati yang lebih tinggi, yang menyebabkan mereka cenderung lebih menolong (Heinzen \& Goodfriend, 2019). Laki-laki lebih mampu dalam melakukan aktivitas fisik yang membutuhkan kekuatan yang lebih besar sementara perempuan lebih tertarik pada kehangatan hubungan interpersonal, hubungan sosial, dan sensibilitas hubungan interpersonal (Istiana, 2018).

\subsection{Strategi dan Desain Penelitian}

Penelitian ini menggunakan strategi penelitian noneksperimental (Gravetter \& Forzano, 2018), dimana variabel perilaku menolong maupun jenis kelamin tidak dilakukan manipulasi oleh peneliti. Sedangkan, desain penelitian yang digunakan dalam penelitian ini adalah desain penelitian diferensial (Gravetter \& Forzano, 2018) dikarenakan peneliti ingin membandingkan perilaku menolong antara remaja akhir perempuan dan remaja akhir laki-laki di KRL rute Jakarta-Bogor.

\subsection{Instrumen Penelitian}

Instrumen yang digunakan dalam penelitian ini adalah skala perilaku menolong untuk mengukur perilaku menolong memberikan tempat duduk di KRL. Untuk membuktikan adanya urutan dalam perilaku memberikan tempat duduk di KRL, peneliti menggunakan skala Guttman. Skala Guttman yang baik memenuhi sifat one-dimensional dan kumulatif sehingga pernyataan-pernyataannya dapat diurutkan dalam suatu dimensi tertentu (Yulianto, 2019). Dengan menggunakan skala Guttman nantinya skala dapat dipastikan hanya mengukur perilaku menolong memberikan tempat duduk di KRL dengan menentukan urutan seperti dugaan peneliti, yaitu remaja akhir yang memberikan tempat duduknya kepada penumpang yang tidak terlalu membutuhkan (seperti, laki-laki dewasa atau perempuan dewasa) kemungkinan juga akan memberikan tempat duduk kepada penumpang yang lebih membutuhkan 
(seperti, ibu hamil atau lansia). Tetapi sebaliknya, jika penumpang remaja akhir yang hanya memberikan tempat duduknya kepada orang yang membutuhkan (seperti ibu hamil atau lansia), maka tidak akan memberikan tempat duduk kepada penumpang yang kurang membutuhkan.

Pernyataan skala terdiri dari delapan jenis penumpang KRL yang bervariasi tingkat kebutuhannya terhadap tempat duduk, yaitu (dari tingkat kebutuhan tertinggi: ibu hamil, ibu mengendong anak, lansia perempuan, lansia laki-laki, penyandang disabilitas perempuan, penyandang disabilitas laki-laki, perempuan dewasa, dan laki-laki dewasa. Setiap jenis penumpang ini menjadi setiap pernyataan dengan pilihan respons "YaTidak" terhadap pertanyaan "mana sajakah yang pernah anda berikan tempat duduk di KRL?".

Untuk setiap pernyataan yang dijawab "Ya" akan diberi skor 1 (satu) dan yang menjawab "Tidak" akan diberi skor 0 (nol). Skor skala perilaku menolong ini dengan menjumlahkan skor dari setiap pernyataan, sehingga skor skala akan berkisar 0 (nol) hingga 8 (delapan). Semakin tinggi skor skalanya, berarti semakin banyak perilaku menolongnya.

\subsection{Teknik Analisis}

Untuk mengetahui apakah perilaku menolong remaja akhir dalam memberikan tempat duduk di KRL Jabodetabek sesuai dugaan peneliti, maka perlu dilakukan analisis skalogram. Analisis skalogram dilakukan untuk mengetahui apakah skala Guttman yang disusun telah memenuhi asumsi one-dimensional dan kumulatif (Yulianto, 2019). One-dimensional artinya skala hanya mengukur sebuah dimensi, sedangkan kumulatif mengacu pada pernyataan-pernyataan skala dapat diurutkan dalam dimensi tersebut berdasarkan skor nya (Yulianto, 2019). Apabila telah memenuhi keduanya, maka pernyataan-pernyataan skala dapat diurutkan serta apakah dengan mengetahui skor total dapat diketahui respons pada skala. Pada analisis skalogram perlu menghitung Coefficient of Reproducibility $(C R)$ dan Coefficient of Scalability $(C S)$. Formula $C R$ ada dalam persamaan (1).

$$
C R=1-\frac{E}{N x k}
$$

Dimana CR (1) adalah Coefficient of Reproducibility, $\mathrm{E}$ adalah jumlah error, $\mathrm{N}$ adalah jumlah responden, dan $\mathrm{k}$ adalah jumlah pernyataan skala. Formula untuk $C S$ ada pada persamaan (2).

$$
C S=1-\frac{E}{M E}
$$

Dimana CS (2) adalah Coefficient of Scalability, E adalah jumlah error, dan ME adalah marginal error. Apabila sebuah skala Guttman mendapatkan CR $\geq 0,90$ dan $\mathrm{CS} \geq 0,60$, maka dapat dikatakan skala tersebut adalah skala yang baik sehingga pernyataan-pernyataan skala dapat diurutkan berdasarkan suatu dimensi tertentu (Yulianto, 2019). Pernyataan-pernyataan skala nantinya dapat diletakkan dalam kontinum agar dapat terlihat urutannya.

Untuk mengetahui apakah ada perbedaan perilaku menolong memberikan tempat duduk di KRL antara remaja akhir perempuan dan remaja akhir laki-laki, dilakukan perhitungan uji beda. Apabila uji asumsi terpenuhi, maka akan digunakan independent sample $t$ test, namun apabila uji asumsi tidak terpenuhi maka akan digunakan Mann-Whitney test.

\section{PEMBAHASAN}

Pengambilan data dilakukan pada bulan Oktober 2020. Jumlah yang mengisi skala sebanyak 448 remaja penumpang KRL rute Jakarta-Bogor, namun sebanyak 59 orang yang mengisi tidak sesuai dengan karakteristik responden yang ditentukan. Oleh karena itu, analisis data berasal dari 389 responden (193 perempuan dan 196 laki-laki) berusia $15-20$ tahun $(M=18,434, S D=1,478)$. Frekuensi responden berdasarkan jenis kelamin, usia, dan domisili ditampilkan pada tabel 1 .

Tabel 1 Frekuensi Responden berdasarkan Jenis Kelamin, Usia, dan Domisili ( $\mathbf{N = 3 8 9 )}$

\begin{tabular}{|l|r|r|r|}
\hline \multicolumn{1}{|c|}{ Variabel } & Perempuan & Laki-laki & Total \\
\hline Jenis Kelamin & 193 & 196 & 389 \\
\hline Usia (tahun) & 13 & & \\
15 & 15 & 7 & 20 \\
16 & 25 & 23 & 30 \\
17 & 41 & 31 & 72 \\
18 & 43 & 58 & 101 \\
19 & 56 & 62 & 118 \\
20 & & & \\
Domisili & 55 & 46 & 101 \\
Jakarta Selatan & 2 & 5 & 7 \\
Jakarta Barat & 10 & 3 & 13 \\
Jakarta Timur & 0 & 0 & 0 \\
Jakarta Utara & 32 & 39 & 71 \\
Tangerang & 43 & 49 & 92 \\
Depok & 45 & 43 & 88 \\
Bogor & 6 & 11 & 17 \\
Bekasi & \multicolumn{3}{|}{} \\
\hline
\end{tabular}

Usia responden yang paling banyak berusia 20 tahun (118 orang) dan usia 15 tahun yang paling sedikit (20 orang). Berdasarkan domisili, tidak ada responden yang berasal dari Jakarta Utara dan Jakarta Selatan adalah domisili yang paling banyak.

Dari analisis skalogram, peneliti telah memperoleh $C R$ dan $C S$ untuk seluruh responden, maupun untuk setiap jenis kelamin. Dari perhitungan dapat diketahui bahwa seluruh $C R$ dan $C S$ telah memenuhi syarat, yaitu mendapatkan $\mathrm{CR} \geq 0,90$ dan $\mathrm{CS} \geq 0,60$. Dengan kata lain, perilaku menolong memberikan tempat duduk di KRL dapat diurutkan berdasarkan dimensi tertentu. $C R$ dan $C S$ ditampilkan pada tabel 2. 
Tabel 2. Coefficient of Reproducibility (CR) dan Coefficient of Scalability (CS) Responden ( $=389$ )

\begin{tabular}{|c|r|r|r|}
\hline Koefisien & \multicolumn{1}{|c|}{ Perempuan } & Laki-Laki & \multicolumn{1}{c|}{ Total } \\
\hline$C R$ & 0,91 & 0,90 & 0,90 \\
\hline$C S$ & 0,61 & 0,61 & 0,62 \\
\hline
\end{tabular}

Untuk mengetahui urutan yang terjadi, dihitung jumlah responden yang menjawab "Ya" pada setiap jenis penumpang KRL yang pernah diberikan tempat duduk. Urutan dibuat berdasarkan data total, dari yang tertinggi (ibu hamil) hingga terendah (pria dewasa). Namun demikian, urutan penumpang KRL yang diberikan tempat duduk pada responden perempuan berbeda dengan responden laki-laki. Frekuensi penumpang yang pernah diberikan tempat duduk oleh responden ditampilkan pada tabel 3 .

Tabel 3. Frekuensi Penumpang yang Pernah Diberikan Tempat Duduk oleh Responden $(N=389)$

\begin{tabular}{|c|c|c|c|}
\hline Penumpang & $\begin{array}{l}\text { Perempuan } \\
(\mathrm{n}=193)\end{array}$ & $\begin{array}{c}\text { Laki-laki } \\
(\mathrm{n}=196)\end{array}$ & $\begin{array}{c}\text { Total } \\
(\mathrm{n}=389)\end{array}$ \\
\hline Ibu hamil & $\begin{array}{r}174 \\
(90,15 \%)\end{array}$ & $\begin{array}{r}196 \\
(100 \%)\end{array}$ & $\begin{array}{r}370 \\
(95,11 \%)\end{array}$ \\
\hline $\begin{array}{l}\text { Ibu menggen- } \\
\text { dong anak }\end{array}$ & $\begin{array}{r}160 \\
(82,90 \%) \\
\end{array}$ & $\begin{array}{r}182 \\
(92,85 \%)\end{array}$ & $\begin{array}{r}342 \\
(87,91 \%) \\
\end{array}$ \\
\hline Lansia perempuan & $\begin{array}{r}179 \\
(92,74 \%) \\
\end{array}$ & $\begin{array}{r}154 \\
(78,57 \%) \\
\end{array}$ & $\begin{array}{r}333 \\
(85,60 \%) \\
\end{array}$ \\
\hline Lansia lak & $\begin{array}{r}166 \\
(86,01 \%) \\
\end{array}$ & $\begin{array}{r}141 \\
(71,93 \%) \\
\end{array}$ & $\begin{array}{r}307 \\
(78,92 \%) \\
\end{array}$ \\
\hline $\begin{array}{l}\text { Penyandang } \\
\text { disabilitas laki- } \\
\text { laki }\end{array}$ & $\begin{array}{r}120 \\
(62,17 \%)\end{array}$ & $\begin{array}{r}102 \\
(52,04 \%)\end{array}$ & $\begin{array}{r}222 \\
(57,06 \%)\end{array}$ \\
\hline $\begin{array}{l}\text { Penyandang } \\
\text { disabilitas } \\
\text { perempuan } \\
\end{array}$ & $\begin{array}{r}105 \\
(54,40 \%)\end{array}$ & $98(50 \%)$ & $\begin{array}{r}203 \\
(52,18 \%)\end{array}$ \\
\hline $\begin{array}{c}\text { Perempuan } \\
\text { dewasa }\end{array}$ & $62(32,12 \%)$ & $\begin{array}{r}117 \\
(59,69 \%) \\
\end{array}$ & $\begin{array}{r}179 \\
(46,01 \%) \\
\end{array}$ \\
\hline Laki-laki dewasa & $31(16,06 \%)$ & $\begin{array}{r}41 \\
(20,91 \%)\end{array}$ & $\begin{array}{r}72 \\
(18,50 \%)\end{array}$ \\
\hline
\end{tabular}

Dengan terpenuhinya CR dan CS untuk untuk masing-masing kelompok, maka dapat dibuat kontinum urutan dari pernyataan-pernyataan skala perilaku menolong. Kontinum urutan perilaku memberikan tempat duduk di KRL untuk partisipan remaja akhir perempuan, dapat dibuat berdasarkan tingkat kebutuhan (dari paling tidak membutuhkan hingga membutuhkan). Bagi remaja perempuan, mereka akan memberikan tempat duduk kepada penumpang KRL, secara berurutan: lansia perempuan, ibu hamil, lansia laki-laki, ibu menggendong anak, penyandang disabilitas laki-laki, penyandang disabilitas perempuan, perempuan dewasa, dan terakhir laki-laki dewasa. Kontinum ini dapat dilihat pada gambar 1 .

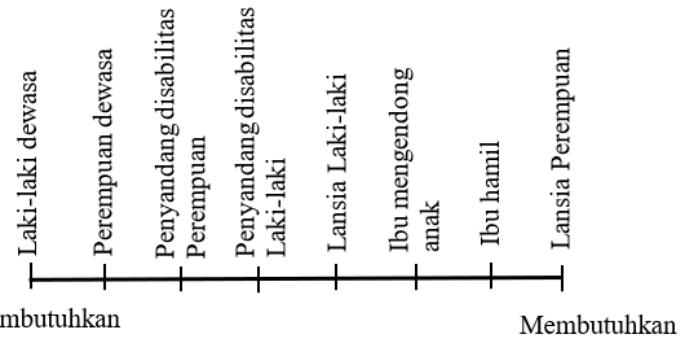
Tempat Duduk di KRL dari Partisipan Perempuan

Dari gambar 1 dapat diketahui apabila remaja akhir perempuan memberikan tempat duduk kepada perempuan dewasa, ia juga akan memberikan tempat duduk kepada penumpang yang dianggap lebih membutuhkan dari perempuan dewasa, seperti penyandang disabilitas, lansia, apalagi ibu hamil. Apabila remaja akhir perempuan mau memberikan tempat duduk kepada laki-laki dewasa (dianggap paling tidak membutuhkan), maka ia juga pasti mau memberikan tempat duduk kepada penumpang lain yang dianggap lebih membutuhkan dibandingkan laki-laki dewasa, seperti perempuan dewasa, penyandang disabilitas hingga ibu hamil dan lansia perempuan. Dan sebaliknya, remaja akhir perempuan yang hanya mau memberikan tempat duduk pada lansia perempuan (dianggap paling membutuhkan), tidak akan memberikan tempat duduk kepada penumpang lain yang dianggap tidak terlalu membutuhkan, seperti ibu hamil, ibu mengendong anak, ataupun lansia laki-laki.

Untuk kontinum urutan perilaku memberikan tempat duduk di KRL untuk partisipan remaja akhir laki-laki, dengan urutan, yaitu: ibu hamil, ibu menggendong anak, lansia perempuan, lansia laki-laki, perempuan dewasa, penyandang disabilitas laki-laki, penyandang disabilitas perempuan dan urutan terakhir yang diberikan pertolongan adalah laki-laki dewasa. Kontinum ini dapat dilihat pada gambar 2 .

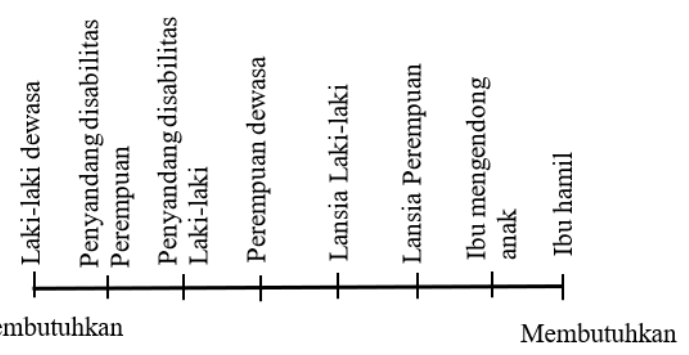

Tidak membutuhkan

Membutuhkan

\section{Gambar 2. Kontinum Urutan Perilaku Memberikan Tempat Duduk di KRL dari Partisipan Laki-laki}

Sama seperti pada remaja akhir perempuan, apabila remaja akhir laki-laki mau memberikan tempat duduk kepada laki-laki dewasa (dianggap paling tidak membutuhkan), maka ia juga pasti mau memberikan tempat duduk kepada penumpang lain yang dianggap lebih membutuhkan dibandingkan laki-laki dewasa, seperti penyandang disabilitas, perempuan dewasa, 
lansia, hingga ibu hamil. Dan sebaliknya, remaja akhir laki-laki yang hanya mau memberikan tempat duduk pada ibu hamil (dianggap paling membutuhkan), tidak akan memberikan tempat duduk kepada penumpang lain yang dianggap tidak terlalu membutuhkan, seperti ibu mengendong anak, lansia, maupun penyandang disabilitas. Remaja akhir laki-laki yang memberikan tempat duduk pada perempuan dewasa, maka pasti akan memberikan kepada lansia, ibu mengendong anak, apalagi ibu hamil.

Dari kedua kontinum di atas, menunjukkan bahwa remaja akhir laki-laki melakukan perilaku menolong berupa pemberian tempat duduk berdasarkan situasi gawat darurat, sedangkan perempuan melakukan perilaku menolong berdasarkan dukungan emosi. Hasil yang diperoleh sesuai dengan penelitian dari Eagly dan Crowley (sebagaimana dikutip dalam Myers \& Twenge, 2019) menyatakan bahwa laki-laki lebih menolong dalam situasi darurat, sedangkan perempuan lebih menolong pada situasi yang bersifat empati (Myers \& Twenge, 2019). Artinya, remaja perempuan memberikan tempat duduk di KRL karena adanya dukungan emosi dengan memberikan pertolongan utama kepada lansia perempuan sedangkan responden laki-laki memberikan pertolongan berupa pemberian tempat duduk di KRL karena adanya situasi darurat dengan memberikan tempat duduknya kepada ibu hamil. Laki-laki lebih menolong ibu hamil karena merasa ibu hamil sedang berada di situasi darurat, dimana ibu hamil bisa saja mengalami kontraksi pada kehamilannya. Sedangkan perempuan lebih menolong lansia perempuan karena merasa kasihan terhadap lansia perempuan terkait dengan kondisi fisik terkait usia.

Untuk mengetahui perbedaan perilaku menolong memberikan tempat duduk di KRL antara remaja perempuan dan remaja laki-laki, dilakukan uji beda. Uji beda dilakukan terhadap skor total dari skala perilaku menolong antara remaja perempuan dan remaja laki-laki. Sebelum itu, dilakukan pengujian asumsi terlebih dahulu, yaitu asumsi normalitas dan homogenitas. Meskipun asumsi homogenitas terpenuhi $(F=2,458, p=0,118)$, dengan Shapiro-Wilk test asumsi normalitas tidak terpenuhi, baik pada kelompok laki-laki $(W=839, p$ $<0,001)$ maupun perempuan $(W=0,898, p<0,001)$. Oleh karena itu, uji beda dilakukan menggunakan MannWhitney test.

Berdasarkan Mann-Whitney test, diketahui perilaku menolong remaja laki-laki $(M=10,128, S D=2,005)$ secara signifikan lebih tinggi dibandingkan perilaku menolong perempuan $(\mathrm{M}=9,332, \quad \mathrm{SD}=2,228), \quad \mathrm{U}=$ $22.789,500, \mathrm{p}=<0,001$. Hasil ini sesuai dengan penelitian (Rosyadi dkk, 2018) yang menemukan hasil bahwa pada mahasiswa STIKes ICME Jombang, laki-laki lebih mungkin memberi bantuan dibandingkan perempuan. Penelitian di New Delhi, India yang mendapatkan hasil bahwa laki-laki lebih tinggi perilaku menolongnya. Selain itu, hal ini sesuai dengan penjelasan Eagly (sebagaimana dikutip dalam Myers \& Twenge, 2019) mengatakan bahwa laki-laki cenderung mau terlibat dalam aktivitas menolong daripada perempuan. Laki-laki lebih sering melakukan perilaku menolong dibandingkan perempuan dikarenakan laki-laki merasa lebih kuat secara fisik untuk melakukan perilaku menolong daripada perempuan. Karena pada remaja akhir perilaku menolong dilakukan berdasarkan tanggungjawab pribadi yang muncul karena telah mengetahui norma yang berlaku di masyarakat (Gupta dan Thapliyal, 2015).

\section{KESIMPULAN}

Perilaku memberikan tempat duduk di KRL termasuk perilaku menolong karena memberikan keuntungan bagi orang lain. Hasil Coefficient of Reproducibility (CR) dan Coefficient of Scalability (CS) menunjukkan hasil bahwa ada perbedaan dalam urutan memberikan pertolongan dimana laki-laki remaja akhir menolong berdasarkan keadaan darurat dan perempuan remaja akhir menolong berdasarkan dukungan emosi. Selain itu, hasil menunjukkan terdapat perbedaan perilaku menolong memberikan tempat duduk antara perempuan remaja akhir dan laki-laki remaja akhir, dimana laki-laki remaja akhir lebih cenderung melakukan perilaku menolong memberikan tempat duduk daripada perempuan usia remaja akhir. Dengan demikian dapat disimpulkan bahwa ada perbedaan perilaku menolong memberikan tempat duduk antara perempuan usia remaja akhir dan laki-laki usia remaja akhir di KRL rute Jakarta-Bogor.

\section{SARAN}

Meskipun hasil penelitian sesuai dengan dugaan peneliti, penelitian ini tidak terlepas dari sejumlah keterbatasan. Untuk itu peneliti memberikan sejumlah saran bagi penelitian serupa di masa mendatang. Pertama, melihat perbedaan perilaku menolong memberikan tempat duduk pada penumpang dewasa. Hal ini dikarenakan kelompok dewasa termasuk penumpang KRL Jabodetabek dengan jumlah lebih besar selain juga memiliki karakteristik psikologis yang berbeda dengan remaja akhir. Kedua, penelitian selanjutnya dapat meneliti perilaku menolong di KRL secara umum, tidak hanya memberikan tempat duduk. Seperti telah disampaikan sebelumnya, cukup perilaku menolong yang terjadi di KRL Jabodetabek. Ketiga, penelitian selanjutnya dapat meneliti faktor-faktor yang mempengaruhi perilaku menolong pada penumpang KRL Jabodetabek. Dengan mengetahui apa saja dan bagaimana pengaruh faktor-faktor tersebut terhadap perilaku menolong, dapat bermanfaat untuk kampanye meningkatkan kepedulian terhadap penumpang lain di KRL Jabodetabek.

\section{DAFTAR PUSTAKA}

Alessandri, G., Kanacri, B. P. L., Eisenberg, N., Zuffianò, A., Milioni, M., Vecchione, M., \& Caprara, G. V. 2014. Prosociality During the Transition From Late Adolescence to Young Adulthood: The Role of Effortful Control and 
EgoResiliency. Personality and Social Psychology Bulletin, 40(11), 1451-1465. https://doi.org/10.1177/0146167214549321

Aprillia, N. G. 2018. Remaja ditegur ibu hamil karena duduk di kursi prioritas, jawabannya bikin netizen geregetan. Grid.Id. https://www.grid.id/read/04211252/2-remajaditegur-ibu-hamil-karena-duduk-di-kursi-prioritasjawabannya-bikin-netizen-geregetan

Branscombe, N. R., \& Baron, R. A. 2017. Social Psychology. Pearson Education Limited.

Graff, J. V. D., Carlo, G., Crocetti, E., Koot, H. M., \& Branje, S. 2018. Prosocial Behavior in Adolescence: Gender Differences in Development and Links with Empathy. Journal Youth Adolescence, 47(5), 1086-1099. https://doi.org/10.1007/s10964-017-0786-1

Gravetter, F. J., \& Forzano, L.-A. B. 2018. Research Methods for the Behavioral Sciences. Cengage Learning, Inc.

Gupta, D., \& Thapliyal, G. 2015. A Study of Prosocial Behaviour and Self Concept of Adolescents. IManager's Journal on Educational Psychology, 9(1), 38. https://doi.org/10.26634/jpsy.9.1.3524

Heinzen, T., \& Goodfriend, W. 2019. Social Psychology. Sage Publications, Inc.

Hogg, M. A., \& Vaughan, G. M. 2018. Social Psychology. Pearson Education Limited.

Irawan, Y. 2018. [Cerita KRL] Pengemis itu bernama ibu hamil.

Kompasiana. https://www.kompasiana.com/yudirawan/5bf6762d 12ae94083c5d2483/cerita-krl-pengemis-itubernama-ibu-hamil

Istiana. 2018. Perbedaan Perilaku Prososial Remaja Ditinjau dari Jenis Kelamin di Kelurahan Tanjung Rejo Medan Sunggal. Jurnal Diversita, 4(1), 5867. https://doi.org/10.31289/diversita.v4i1.1592

Jang, S., Allen, T. D., Kim, E., \& Cho, S. 2020. An Examination of the Temporal Order of Helping Behaviours and Emotional Exhaustion. Stress and Health, 36(5), 663-674. https://doi.org/10.1002/smi.2943

Kennedy, P. E. 2013. The Relationship Between Prosocial Music and Helping Behaviour and its Mediators: An Irish College Sample. Journal of European Psychology Students, 4, 1-5.

Myers, D. G., \& Twenge, J. M. 2019. Social Psychology (13th ed.). McGraw-Hill Education.

Rahayu, Y. A. 2019. 28,1 juta orang naik KRL selama april 2019. Merdeka.Com. https://www.merdeka.com/uang/281-juta-orangnaik-krl-selama-april-2019.html

Randall, J. G., Zimmer, C. U., O’Brien, K. R., TrumpSteele, R. C. E., Villado, A. J., \& Hebl, M. R. 2018. Weight Discrimination in Helping Behavior. Revue Européenne de Psychologie Appliquée, 67, 127-137.

https://doi.org/10.1016/j.erap.2017.02.002
Rosyadi, A. E. A., Rosyidah, I., \& Nofalia, I. 2018. Empati dan Perilaku Altruisme Mahasiswa. Insan Cendekia, 5(1), 21-28.

Septianingsih, N. 2017. Hubungan antara Regulasi Emosi dengan Perilaku Prososial pada Remaja Akhir (mahasiswa). Universitas Mercu Buana Yogyakarta.

Sunarti, E., Islamia, I., Rochimah, N., \& Ulfa, M. 2018. Resiliensi Remaja: Perbedaan Berdasarkan Wilayah, Kemiskinan, Jenis Kelamin, dan Jenis Sekolah. Jurnal Ilmu Keluarga \& Konsumen, 11(2), 157-168.

Yulianto, A. 2019. Penyusunan Skala Guttman untuk Pengukuran Psikologi. Universitas Pembangunan Jaya.

Yulianto, A. 2020. Pengujian Psikometri Skala Guttman untuk Mengukur Perilaku Seksual pada Remaja Berpacaran. Jurnal Psikologi: Media Ilmiah Psikologi, 18(1), 38-48. https://doi.org/10.47007/jpsi.v18i01.80 